not important provided every effort is made to collect the data.

Consultant Neurologist, Hospital for Sick Children,

E M BRETT

Great Ormond Street, London WCIN 3JH

1 Whitley RJ, Seng-Jaw S, Hirsch M, et al. Herpes simplex encephalitis: vidarabine therapy and diagnostic problems. N Engl f Med 1981;304:313-8.

McCrossin DB, Gilbert GL. Herpes simplex virus encephalitis in children. Med $\mathcal{J}$ Aust 1986;144:711-3.

3 Upton A, Gumpert J. Electroencephalography in herpes simplex encephalitis. Lancet 1970; 650-2.

4 Schauseil-Zipf U, Harden A, Hoare R, et al. Early diagnosis of herpes simplex encephalitis in childhood. Eur I Pediatr 1982;138:154-61.

Nahmias AJ, Whitley RJ, Visintine AN, et al. Herpes simplex virus encephalitis: laboratory evaluations and their diagnostic significance. I Infect Dis 1982;145:829-36.

6 Koskiniemi A, Vaheri A, Taskinen E. Cerebrospinal fluid alterations in herpes simplex virus encephalitis. Rev Infect Dis 1984;6:608-18.

Dwyer DE, O'Flaherty SO, Packham D, et al. Herpes simplex encephalitis in infants. Med f Aust 1986;144:714-5.

8 Longson M. Herpes simplex encephalitis. In: Matthews WB, Glaser GH, eds. Recent advances in linical neurology. Vol 4. Edinburgh: Churchill Livingstone, 1984:123-39.

9 Skoldenberg B, Forsgren M, Alestig K, et al. Acyclovir versus vidarabine in herpes simplex encephalitis. Randomised multicentre study in consecutive Swedish patients. Lancet 1984;ii: 707-11.

10 Whitley RJ, Alford CA, Hirsch MS. Vidarabine versus acyclovir therapy in herpes simplex encephalitis. N Engl f Med 1986;314:144-9.

\section{Carcinoma in situ of the testis}

The contralateral testes of men with testicular cancer and testes from infertile men and those with a history of maldescent may contain premalignant cells-carcinoma in situ. ${ }^{1}$ Detection of those cells may allow the early cancer to be cured,$^{2}$ and a recent meeting in Copenhagen reviewed the possibilities. ${ }^{3}$

Skakkebaek, who first described carcinoma in situ of the testis, has proposed calling the condition "gonocytoma in situ" to reflect the similarities between the premalignant cells and the primordial germ cells (or gonocytes) in the embryonic gonad. ${ }^{4}$ Some researchers believe that carcinoma in situ is the precursor of all germ cell tumours with the possible exception of spermatocytic seminoma. This theory has arisen because carcinoma in situ has the potential to progress to both seminomatous and non-seminomatous germ cell tumours $^{56}$ and because atypical cells may be found in cryptorchid testes from prepubescent boys.

Testicular biopsy is the only reliable way to detect carcinoma in situ, although the abnormal cells may be missed. The cells do, however, seem to be spread through the testis and are therefore likely to be detected by random biopsy $^{8}$ : none of 473 men with testicular cancer who had negative biopsy examinations of the contralateral testis went on to develop tumours. ${ }^{9}$ The diagnosis also depends on good specimen preparation, and a new development is using immunoperoxidase and antibodies against placental alkaline phosphatase. This appears to stain carcinoma in situ cells as well as seminoma cells.

Carcinoma in situ is most common in seminiferous tubules adjacent to a germ cell tumour but may be present in about $5 \%$ of the contralateral testes from men with tumours (p 1398). It may also occur in $2 \%$ of biopsy specimens from adult men with a history of maldescent of the testis ${ }^{9}$ and in $0 \cdot 4-1 \%$ of specimens from infertile men. ${ }^{10-12}$ Reports of carcinoma in situ have come from Europe, ${ }^{10-13}$ the USSR, ${ }^{14}$ North America, ${ }^{15}$ and Japan, ${ }^{16}$ but there have been no prospective studies. The fourth group of men at risk have gonadal dysgenesis, androgen insensitivity, or a $45 \mathrm{XO}$, $46 \mathrm{XY}$ karotype. In these rare disorders the risk may be as high as $80 \% .^{17}$
The risk of carcinoma in situ progressing to a germ cell tumour is substantial. ${ }^{10}$ In a series from London eight men with carcinoma in situ were detected among 2043 infertile men who underwent biopsy and six have subsequently developed tumours. ${ }^{10}$

Men with gonadal dysgenesis should certainly undergo biopsy, but which other men should is not yet agreed. Von der Masse and others ( $p$ 1398) recommend that surgeons should take a biopsy specimen from the contralateral testes from all men with testicular cancer. Such a policy would certainly teach us about the effect of chemotherapy on carcinoma in situ, which is important because the testis is said to be a sanctuary site and the current trend is to use shorter and less toxic drug regimens. Men with metastases who will receive chemotherapy anyway probably do not need biopsy. Doctors recommending orchidectomy and then surveillance rather than chemotherapy or radiotherapy for men with early stage germ cell tumours should consider biopsy of the contralateral testis. ${ }^{18} \mathrm{My}$ policy is to perform biopsy of the contralateral testis at the time of orchidectomy if the tumour seems to be localised. I judge which tumours are at an early stage from clinical examination, chest radiography, and abdominal ultrasonography, and I accept that subsequent detailed investigation may prove me wrong.

Deciding whether men with testicular maldescent or infertility should undergo biopsy is more difficult. The incidence of testicular maldescent appears to be increasing in England and Wales (p 1401) (19 $^{9}$ and in Scotland, ${ }^{20}$ and, worryingly, early orchidopexy may not protect against infertility. ${ }^{21}$ Danish experience suggests that infertile men at risk of carcinoma in situ usually have no azospermia but a low sperm concentration (less than 20 millions per $\mathrm{ml}$ ) and reduced testis volume (less than $12 \mathrm{ml}$ ). ${ }^{3}$ They may also have a history of testicular pain associated with a decrease and then an increase in testicular size. Self examination of the testis ${ }^{22}$ may thus help in diagnosis, and further help may come from the World Health Organisation task force on infertility adapting the Praadar orchidometer to make it more suitable for examining adult men. Ultrasonography and nuclear magnetic resonance are currently being evaluated as noninvasive methods of screening, ${ }^{3}$ but other techniques would be welcome.

The British reluctance to search for carcinoma in situ may result partly from lack of awareness of the condition and partly because the true risk of progression is only now becoming apparent. Also doctors have hesitated to recommend bilateral orchidectomy to young men with a unilateral tumour and contralateral carcinoma in situ or a unilateral orchidectomy to men with infertility. A recent preliminary report from Denmark that low dose irradiation $(20 \mathrm{~Gy})$ will abolish carcinoma in situ is an exciting development that needs confirmation. ${ }^{23}$

Standard treatment remains orchidectomy, but low dose radiotherapy seems to be an option for men with bilateral carcinoma in situ or carcinoma in situ in the single remaining testis. Chemotherapy regimens that include platinum will probably abolish carcinoma in situ in the contralateral testis, but we lack data.

Carcinoma in situ of the testis is now clearly described, and the men at risk have been defined. Now the knowledge must be used to prevent tumours and to reduce the numbers of men with metastatic disease.

T B HARGREAVE

Senior Lecturer,

Department of Urology,

Western General Hospital,

Edinburgh EH4 2XU 
1 Skakkebaek NE. Possible carcinoma in situ of the testis. Lancet 1972;ii:516-7.

2 Anonymous. Testisticular biopsy for early detection of testicular tumour [Editorial]. Br Med $\mathcal{J}$ 1980;1280:426-7

3 Rorth M, Grigor KM, Giwercman A, Dawgaard G, Skakkebaek N, eds. Carcinoma-in-situ and testis cancer: biology and treatment. Proceedings of $a$ Workshop on Testis Cancer held in Copenhagen 1986. Oxford: Blackwell Scientific Publications, in press.

4 Skakkebaek NE, Bethelsen JG, Giwercman A, Muller J. Carcinoma-in-situ of the testis: possible origin from genocytes and precursor of all types of germ cell tumours except spermatocytoma. Int $\mathcal{7}$ Androl (suppl 7), in press.

5 Muller J, Skakkebaek NE, Nielsen OH, Graem N. Cryptorchidism and testis cancer. Cancer 1984;54:629-34.

Stein NA, Jain R. Testicular intratubular origin of choriocarcinoma. Urology 1982;20:296-7.

7 Skakkebaek NE, Berthelsen JG, Muller J. Carcinoma-in-situ of the undescended testis. Urol Clin North Am 1982;9:377-85.

8 Berthelsen JG, Skakkebaek NE. Distribution of carcinoma in situ in the testis from infertile men. Int 7 Androl $1981 ; 4$ (suppl) $): 172-84$

Krabbe S, Skakkebaek NE, Berthelsen JG, et al. High incidence of undetected neoplasia in maldescended testes. Lancet 1979;i:999-1000.

10 Pryor JP, Cameron KM, Chilton CP, et al. Carcinoma in situ in testicular biopsies from men presenting with infertility. $B r \mathcal{F}$ Urol 1983;55:780-4

11 West AB, Butler MR, Fitzpatrick J, O'Brien A. Testicular tumors in subfertile men: report of 4 cases with implications for management of patients presenting with infertility. $\mathcal{J}$ Urol 1985;133:1-9.

12 Skakkebaek NE. Carcinoma in situ of the testis: frequency and relationship to invasive germ cell tumours in infertile men. Histopathology 1978;2:157-70.

13 Nuesch-Bachmann IH, Hedinger C. Atypische spermatogonien als Prakanzerose. Schweiz Med Wochenschr 1977;107:795-801.

14 Romanenko AM, Persidskii IuV. Znachenie atipichnykh polovykh kletok $\mathbf{v}$ gistogeneze germinativnykh opukholei iaichka; The importance of atypical cells in histogenesis of germ cell germinativnyk opukholei iaichka, The importance of atypical cells 8 .

15 Williams TR, Bendler H. Carcinoma in situ of the ectopic testis. F Urol 1977;117:610-2.

16 Ishida $\mathrm{H}$, Isurugi $\mathrm{K}$, Nijijima T, et al. Carcinoma in situ germ cells and subsequent development of an invasive seminoma in a hyperprolactinaemic man. Int $\mathcal{f}$ Androl 1983;6:229-34.

17 Muller J, Skakkebaek NS. Testicular carcinoma in situ in children with the androgen insensitivity suller J, Skakkebaek NS. Testicular carcinoma in situ in children with the androme (testicular feminsation syndrome). $B r$ Med $\mathcal{F} 1984 ; 288: 1419-20$.
syndrom

18 Peckham MJ, Barret A, Husband JE, Hendry WF. Orchiectomy alone in testicular stage 18 nonseminomatous germ cell tumours. Lancet 1977; ii:678-80.

19 Chilvers C, Pike MC, Forman D, Fogelman K, Wadsworth MEJ. Apparent doubling of frequency of undescended testis in England and Wales in 1962-81. Lancet 1984;ii:330-2.

20 Hargreave TB, Elton RA, Webb Jennifer A, Busuttil A, Chisholm GD. Maldescended testes and fertility: a review of 68 cases. Br $\mathcal{F}$ Urol 1984;56:734-9.

21 Pike MC, Chilvers C, Peckham MJ. Effect of age at orchidopexy on risk of testicular cancer. Lancet 1986; : 1246-8.

22 Thornhill JA, Conroy RM, Kelly DG, Walsh A, Fennelly JJ, Fitzpatrick JM. Public awareness of testicular cancer and the value of self examination. $\mathrm{Br}$ Med $\mathcal{f}$ 1986;293:480-1.

23 von der Maase H, Giwercman A, Skakkebaek NE. Radiation treatment of carcinoma in situ of testis. Lancet 1986;: $624-5$.

\section{The decline in the teaching of legal medicine}

The teaching of legal medicine and ethics in British medical schools is "barely sufficient for the needs of today" and is declining, conclude Knight and Thompson in a recent review. ${ }^{1}$ Replies from the deans of 19 medical schools showed that the amount of time spent lecturing on legal medicine varied from three to 39 hours, and eight deans reported that the amount of teaching time had fallen since 1976. About two thirds of 75 students and 77 recently qualified doctors who answered questionnaires thought that the teaching of legal medicine was inadequate. The most powerful indictments came from coroners: "I am amazed and appalled at the lack of knowledge of many doctors relating to their responsibilities in regard to the types of death which require notification to the coroner"; "My experience is that the average doctor does not know what to do when faced with the abnormal or suspicious death."

The educational committee of the General Medical Council and the advisory committee on medical training of the Commission of the European Community have both stated that newly qualified doctors should have an adequate knowledge of the laws concerning medical practice. The BMA annual representative meeting in Scarborough this year resolved that the GMC should instruct individual medical schools to have an identifiable and substantial part of the undergraduate medical curriculum devoted to the ethical and legal aspects of medical practice. ${ }^{2}$ Knight and Thompson's results suggest that many do not.

The decline in medicolegal instruction to students can be traced back to the time when a separate examination in forensic medicine was abolished in the final qualifying examination. Since then the time devoted to this instruction has been eroded by the many specialties that have mushroomed in the past 30 years. Medical students attend courses on many subjects that may be of little or no practical value to them after qualification, but no matter what branch of medicine or surgery the graduate enters he will always have to face medicolegal problems. If he is in general practice these may occur daily.

Many doctors are ignorant even about death certification. In some hospitals the junior doctor is told what he should put on a death certificate by a clerk in the office or by the mortuary superintendent. Little wonder that relatives are upset by having to delay funeral arrangements because the registrar of births and deaths has been unable to accept the certified cause of death. Both junior and senior doctors are often unaware of which deaths should be referred to the coroner, although lists of such deaths are readily available from the medical defence and protection societies and from reference to any standard book on forensic medicine. The list also appears in the preface to each book of death certificates.

What are the basic medicolegal requirements of the medical student? He should know the legal responsibility of correct death certification and the deaths that should be referred to the coroner. He should be able to write medicolegal reports for the coroner and courts that can be understood by non-medical people and are devoid of ambiguities. He must know his responsibilities under the various drugs and human tissues acts, and he must be able to conduct a medicolegal examination in cases of alleged assaults and of sexual offences. This requires a knowledge of patterns of injury and the ability to separate deliberate from accidental wounds. He must also understand confidentiality and medical ethics.

An ad hoc committee of medicolegal experts representing the countries of the European Community met recently in Seville to discuss the harmonisation of medicolegal teaching to both undergraduates and postgraduates. This harmonisation is required to fulfil the provisions of the Treaty of Rome on the free circulation of professional men throughout the community. The final report, which will be presented to the European Parliament in Strasburg, recommends that undergraduates receive a minimum of 60 hours medicolegal instruction during their final two clinical years. The student should be required then to pass an examination to show that he had acquired an adequate knowledge of medicolegal matters before starting to practise medicine.

Medicolegal departments on the Continent often cover all aspects of forensic medicine and science, including psychiatry and assessment of disabilities (insurance medicine), which are dealt with by other departments in Britain. Nevertheless, even if psychiatry, insurance medicine, industrial medicine, and laws relating to drugs are dealt with by other departments, an undergraduate course of some 30-40 lectures and demonstrations in legal medicine would still be essential to attain the basic European standard. Unless this is done medicolegal standards will continue to decline-to the detriment of the community.

A KeIth MaNT

Emeritus Professor of Forensic Medicine,

Guy's Hospital,

London SE1 9RT

1 Knight B, McKim Thompson I. The teaching of legal medicine in British medical schools. Med Educ 1986;20:246-58.

2 Anonymous. Briefing: from the annual representatives' meeting [Editorial.] BMA News Review 1986;12(Sept):33. 